\title{
Microwave-assisted hydrolysis and extraction of tricyclic antidepressants from human hair
}

\author{
Renata Wietecha-Posłuszny • Aneta Garbacik • \\ Michał Woźniakiewicz • Pawel Kościelniak
}

Received: 15 September 2010 /Revised: 9 November 2010/Accepted: 12 November 2010 / Published online: 4 December 2010

(C) The Author(s) 2010. This article is published with open access at Springerlink.com

\begin{abstract}
The objective of this research was to develop, optimize, and validate a modern, rapid method of preparation of human hair samples, using microwave irradiation, for analysis of eight tricyclic antidepressants (TCADs): nordoxepin, nortriptyline, imipramine, amitriptyline, doxepin, desipramine, clomipramine, and norclomipramine. It was based on simultaneous alkaline hair microwave-assisted hydrolysis and microwave-assisted extraction (MAH-MAE). Extracts were analyzed by high-performance liquid chromatography with diode-array detection (HPLC-DAD). A mixture of $n$-hexane and isoamyl alcohol $(99: 1, v / v)$ was used as extraction solvent and the process was performed at $60^{\circ} \mathrm{C}$. Application of $1.0 \mathrm{~mol} \mathrm{~L} \mathrm{~L}^{-1} \mathrm{NaOH}$ and microwave irradiation for $40 \mathrm{~min}$ were found to be optimum for hair samples. Limits of detection ranged from 0.3 to $1.2 \mu \mathrm{g} \mathrm{g}^{-1}$ and LOQ from 0.9 to $4.0 \mu \mathrm{g} \mathrm{g}^{-1}$ for the different drugs. This enabled us to quantify them in hair samples within average therapeutic concentration ranges.
\end{abstract}

Keywords Tricyclic antidepressants · Hair analysis . Microwave-assisted hydrolysis · Microwave-assisted extraction

Published in the special issue Focus on Analytical Science in Poland (VIIIth Polish Conference on Analytical Chemistry) with Guest Editor Paweł Kościelniak.

R. Wietecha-Posłuszny $(\bowtie) \cdot$ A. Garbacik $\cdot$ M. Woźniakiewicz •

P. Kościelniak

Laboratory for Forensic Chemistry,

Department of Analytical Chemistry, Jagiellonian University,

3 Ingardena St,

30-060 Kraków, Poland

e-mail: wietecha@chemia.uj.edu.pl

P. Kościelniak

Institute of Forensic Research,

9 Westerplatte St,

31-033 Kraków, Poland

$\begin{array}{ll}\text { Abbreviations } & \\ \text { 6AM } & \text { 6-Monoacetylmorphine } \\ \text { Ami } & \text { Amitriptyline } \\ \text { BZE } & \text { Benzoylecgonine } \\ \text { CCE } & \text { Cocaethylene } \\ \text { Clo } & \text { Clomipramine } \\ \text { DCM } & \text { Dichloromethane } \\ \text { Des } & \text { Desipramine } \\ \text { Dox } & \text { Doxepin } \\ \text { GC-MS } & \text { Gas chromatography with mass } \\ & \text { spectrometric detection } \\ \text { HPLC-DAD } & \text { High-performance liquid chromatography } \\ & \text { with diode-array detection } \\ \text { HS-SPME } & \text { Head space solid-phase microextraction } \\ \text { Imi } & \text { Imipramine } \\ \text { IS } & \text { Internal standard } \\ \text { LLE } & \text { Liquid-liquid extraction } \\ \text { LOD } & \text { Limit of detection } \\ \text { LOQ } & \text { Limit of quantification } \\ \text { MAE } & \text { Microwave-assisted extraction } \\ \text { MAH } & \text { Microwave-assisted hydrolysis } \\ \text { MeOH } & \text { Methanol } \\ \text { Norc } & \text { Norclomipramine } \\ \text { Nord } & \text { Nordoxepin } \\ \text { Nort } & \text { Nortriptyline } \\ \text { PFPA } & \text { Pentafluoropropionic acid } \\ \text { SPE } & \text { Solid-phase extraction } \\ \text { TCADs } & \text { Tricyclic antidepressants } \\ & \end{array}$

Introduction

Remarkable advances in sensitive analytical techniques have enabled the analysis of substances in such unconventional 
biological specimens as hair [1]. In recent years, hair analysis has become prevalent in forensic and clinical toxicology [24]. Various organic substances have been found and determined in hair, e.g. drugs of abuse, psychotropic drugs, doping agents, steroids, alcohol, and their metabolites [5-7]. Moreover, correlations have been found between concentrations of drugs in plasma and hair. Kintz et al. showed that when the concentration of clozapine in plasma was elevated, the corresponding hair content of this drug also increased [8]. In another study, Pragst et al. indicated that drugs are about ten times more concentrated in hair than in plasma [9]. The results of studies of Beumer et al. also showed a correlation between plasma and the hair concentration of such psychotropic drugs as carbamazepine, amitriptyline, and chlorpromazine [10].

Toxicologically, hair belongs to the group of so-called alternative materials (similarly to sweat, oral fluid, nails, vitreous humor, meconium, and tears). Hair analysis provides a wide window of detection of xenobiotics and their metabolites, because many compounds become incorporated into the structure of hair. Thus, it provides information on drug intake for a long time after the drug has been excreted from the human body $[9,11]$. Moreover, it has been shown elsewhere that hair analysis gives great possibilities of distinguishing between acute, chronic, and one-time substance use [12, 13].

The first time a hair sample was used for toxicological analysis was in the 18th century for determination of arsenic in a postmortem hair sample [14]. However, it was not until Baumgartner et al. carried out research in 1979 on the application of a radioimmunological method for detection of opiates in hair that analysis of this kind of biological matrix began to develop rapidly [3, 15]. The determination of psychotropic drugs, for example benzodiazepines, neuroleptics, anesthetics, hypnotics, and sedatives, has recently been reviewed by Wada et al. [5]. Examples of determination of frequently prescribed [16] tricyclic antidepressants (TCADs) have also been published [9, 17-20].

TCADs have been used for treatment of depression since the middle of the 20th century. The therapeutic mechanism of tricyclic antidepressants is still not known, but it is probably related to reduced norepinephrine and serotonin reuptake. However, because of their narrow therapeutic range, these drugs are often overdosed and used for self-poisoning [16]. Moreover, they are more toxic than selective serotonin reuptake inhibitors, but despite this drawback they are still prescribed because of their high and proved efficacy in the treatment of patients.

The mechanism of drug incorporation into hair has still not been clarified. Chemical and physical properties of drugs (for example lipophilicity, $\mathrm{p} K_{\mathrm{a}}$ ) and hair structure (the isoelectric $\mathrm{pH}$ of hair is approximately 6) have a strong effect on the mechanism of incorporation [3, 4, 13]. The affinity of particular substances for hair probably also depends on the melanin content, which is acidic $(\mathrm{pH} \mathrm{3-5)}$
[9]. This may be a reason why basic drugs, for example TCADs, are more readily absorbed into hair than acidic substances [3]. Moreover, deposition of hydrophilic metabolites into hair is less efficient than deposition of the parent drug [18]. The opposite situation is observed for blood, in which the concentrations of the parent drugs are lower than those of their metabolites. Reference TCAD concentrations in hair cover a wide range from $<0.1$ to $183.3 \mu \mathrm{g} \mathrm{g}^{-1}[3,9,17,19,20]$. It should be emphasized that there is no specified concentration range correlated with dosage or treatment, and the reported concentration varies between authors.

Hair analysis provides much valuable information, but pretreatment of hair samples is time-consuming and laborious. The chemical structure of a drug and its sensitivity to agents used for sample preparation should be taken into consideration. First, hair should be washed (with, e.g., sodium dodecylsulfate solution) and dried at room or elevated temperature. The sample must then be digested in alkaline or acidic solution [18]. Enzymatic hydrolysis may also be applied [21], and a simple methanolic bath [18]. In the next step, the analytes are isolated with an extraction technique, for example liquid-liquid extraction [22], solid-phase extraction [23], or solid-phase microextraction [24]. These steps may take up to $12 \mathrm{~h}$ or more, which is why it is so important to develop a fast and simple hair-sample-preparation technique. The most commonly used sample-preparation techniques, with additional information about subsequent extraction and method of analysis, are presented in Table 1.

In recent years, much attention has been devoted to application of microwave energy in sample preparation. Microwave-assisted extraction (MAE) is a process which involves using microwave energy to heat the extraction solvent-sample system and to transfer compounds of interest from the matrix into the extraction solvent. Supporting the liquid-liquid extraction with microwaves can make the MAE method even more efficient than conventional extraction techniques [27]. The main advantages of using microwave irradiation at the preparation stage are reduction of extraction time, reduced consumption of solvents, and increased recovery of an isolated analyte. Moreover, it is easy to perform.

Microwave irradiation was used for the first time in the laboratory by Abu-Samara et al. to prepare biological samples for trace analysis of metals [28]. Since then, microwaveassisted extraction has also been successfully applied to preparation of samples for analysis of organic compounds in difficult matrices, for example blood, serum, plasma, urine, saliva, human hair, tablets, and suppositories [29-37].

The first paper about the application of microwave-assisted extraction in hair analysis was published by Álvarez et al in 2009 [37]. They described a simple and rapid method for isolation of ethyl glucuronide - a promising general marker of alcohol consumption-from hair by MAE. Another paper devoted to application of MAE in hair analysis was 
Table 1 Conventional sample preparation and extraction methods for TCADs from hair

\begin{tabular}{|c|c|c|c|c|}
\hline Drugs & Pretreatment & Extraction procedure & Method of analysis & Ref \\
\hline Amitriptyline, doxepin & $\begin{array}{l}\text { Alkaline digestion } \\
10-20 \mathrm{mg} \text { hair with } 0.1 \mathrm{~mol} \mathrm{~L}^{-1} \\
\mathrm{NaOH} \text { at } 80^{\circ} \mathrm{C} \text { for } 30 \mathrm{~min} \\
\text { Acidic hydrolysis } \\
10-20 \mathrm{mg} \text { hair incubated in } 1 \mathrm{~mL} \\
0.1 \mathrm{~mol} \mathrm{~L}{ }^{-1} \mathrm{HCl} \text { at } 45^{\circ} \mathrm{C} \text { for } 18 \mathrm{~h} \\
\text { Methanol extraction } \\
10-20 \mathrm{mg} \text { of hair with } 2 \mathrm{~mL} \\
\text { methanol in an ultrasonic } \\
\text { bath for } 1 \mathrm{~h} \text {, then incubation } \\
\text { at room temperature overnight }\end{array}$ & $\begin{array}{l}\text { LLE from } \mathrm{pH} \text { 9.5-10 to ether; } \\
\text { dry residue dissolved in } \mathrm{MeOH}\end{array}$ & GC-MS & {$[18]$} \\
\hline $\begin{array}{l}\text { Amitriptyline (nortriptyline), } \\
\text { clomipramine (norclomipramine), } \\
\text { doxepin (nordoxepin), imipramine } \\
\text { (desipramine) }\end{array}$ & $\begin{array}{l}\text { Alkaline digestion } \\
7-30 \mathrm{mg} \text { hair with } 0.1 \mathrm{~mol} \mathrm{~L}^{-1} \\
\mathrm{NaOH} \text { at } 80{ }^{\circ} \mathrm{C} \text { for } 30 \mathrm{~min} \\
\text { Methanol extraction } \\
7-30 \mathrm{mg} \text { hair with methanol, } \\
\text { in ultrasonic bath for } 2 \mathrm{~h} \text {, } \\
\text { then incubation for } 18 \mathrm{~h}\end{array}$ & $\begin{array}{l}\text { LLE (Extrelut column) } \\
\text { ethyl acetate-ether }(1: 1, v / v) \text {, } \\
\text { evaporation to dry residues, } \\
\text { derivatization with PFPA, } \\
\text { dry residue dissolved in ethyl } \\
\text { acetate }\end{array}$ & GC-MS & [9] \\
\hline $\begin{array}{l}\text { Amitriptyline, doxepin, } \\
\text { imipramine, triimipramine }\end{array}$ & $\begin{array}{l}\text { Alkaline digestion } \\
10 \mathrm{mg} \text { hair with a mixture of } 1 \mathrm{~mL} 0.4 \% \\
\mathrm{NaOH} \text { and } 0.5 \mathrm{~g} \mathrm{Na}_{2} \mathrm{SO}_{4} \text { for } 30 \mathrm{~min}\left(90^{\circ} \mathrm{C}\right)\end{array}$ & $\begin{array}{l}\text { HS-SPME to polyacrylate fiber } \\
(85 \mu \mathrm{m}) \text {; fiber exposure } \\
\text { for } 20 \mathrm{~min}\end{array}$ & GC-MS & {$[24]$} \\
\hline $\begin{array}{l}\text { Amitriptyline (nortriptyline), } \\
\text { doxepin (nordoxepin), imipramine } \\
\text { (desipramine) trimipramine }\end{array}$ & $\begin{array}{l}\text { Alkaline digestion } \\
5-25 \mathrm{mg} \text { hair with } 1 \mathrm{~mL} 1 \mathrm{~mol} \mathrm{~L} \\
\text { NaOH, incubation for } 30 \mathrm{~min} \text { at } 70{ }^{\circ} \mathrm{C} \\
\text { Acidic hydrolysis } \\
5-25 \mathrm{mg} \text { hair with } 1 \mathrm{~mL} 0.1 \mathrm{~mol} \mathrm{~L}^{-1} \\
\mathrm{HCl} \text { for } 18 \mathrm{~h} \text { at } 55^{\circ} \mathrm{C} \\
\text { Methanol extraction } \\
5-25 \mathrm{mg} \text { hair with } 1 \mathrm{~mL} \text { methanol } \\
\text { for } 18 \mathrm{~h} \text { at } 70^{\circ} \mathrm{C} \\
\text { Enzymatic hydrolysis } \\
5-25 \mathrm{mg} \text { hair with subtilisin for } \\
18 \mathrm{~h} \text { at } 55^{\circ} \mathrm{C}\end{array}$ & $\begin{array}{l}\text { LLE from alkaline medium to } \\
\text { hexane-butanol }(95: 1, v / v) \\
\text { back-extraction to } 0.2 \% \\
\text { orthophosphoric acid }\end{array}$ & HPLC & {$[25]$} \\
\hline Amitriptyline, clomipramine & $\begin{array}{l}\text { Acid hydrolysis } \\
75 \mathrm{mg} \text { ground hair with } 1 \mathrm{~mL} \\
0.1 \mathrm{~mol} \mathrm{~L}{ }^{-1} \mathrm{HCl} \text { for } 12 \mathrm{~h} \text { at } 56{ }^{\circ} \mathrm{C}\end{array}$ & $\begin{array}{l}\text { SPE }\left(\mathrm{C}_{18}\right) \text { : elution solvent: } \\
\text { methanol with } 0.5 \% \text { glacial } \\
\text { acetic acid; dry residue } \\
\text { dissolved in } \mathrm{MeOH}\end{array}$ & HPLC & {$[26]$} \\
\hline
\end{tabular}

published in 2009. Fernandez et al. [34] successfully used microwave irradiation for simultaneous extraction of six illegal drugs of abuse (cocaine, BZE, CCE, morphine, $6 \mathrm{AM}$, and codeine) from human hair samples. The recoveries of isolated drugs were close to $100 \%$. The optimum MAE method was compared with the MAE technique preceded by enzymatic or acid digestion. When the procedures as a whole were compared, it was found that similar recoveries were achieved-ranging from 86 to $100 \%$.

However, to the best of our knowledge, there has been no publication describing the application of microwave radiation to isolation of tricyclic antidepressant drugs from human hair. As TCADs are still commonly prescribed drugs, there is a persistent need to develop effective methods for isolation of these compounds from a variety of matrices. Within the framework of this research, simultaneous microwave-assisted hydrolysis and extraction (MAH-MAE) of tricyclic antidepressants from human hair has been developed. Sample preparation was followed by analysis by high-performance liquid chromatography with diode-array detection. The method was optimized and validated for analysis of eight TCADs and their metabolites (Ami, Des, Dox, Imi, Nord, Nort, Norc, and Clo) in human hair for forensic and clinical purposes.

\section{Experimental}

Reagents and materials

HPLC-gradient-grade acetonitrile and methanol were supplied by Merck (Darmstadt, Germany). Orthophosphoric acid (85\%), $30 \%$ aqueous $\mathrm{NaOH}$ solution, $n$-hexane, acetone, and isoamyl 
alcohol, all of analytical grade, were purchased from POCh (Gliwice, Poland). Drug standards, sodium dodecylsulfonate, and diethylamine were purchased from Sigma-Aldrich (St Louis, MO, USA). Deionized water $\left(<1.0 \mu \mathrm{S} \mathrm{cm}^{-1}\right)$ was used throughout.

\section{Standards}

Drug stock solutions $\left(10 \mathrm{mg} \mathrm{mL} L^{-1}\right)$ were prepared in methanol and stored in a refrigerator $\left(+4^{\circ} \mathrm{C}\right)$. Spiking solutions were prepared daily by appropriately diluting stock solutions with deionized water. Standard drug solutions were prepared by diluting stock solutions with $0.05 \% \mathrm{H}_{3} \mathrm{PO}_{4}$ to a concentration of $3.6 \mu \mathrm{g} \mathrm{mL}^{-1}$ (corresponding to $4 \mu \mathrm{g} \mathrm{g}^{-1}$ in a 45-mg hair sample). Each drug: Ami, Des, Dox, Imi, Nord, Nort, Norc and Clo was tested in the concentration range 2.5-20.0 $\mu \mathrm{g} \mathrm{g}^{-1}$ hair. Clomipramine $\left(40 \mu \mathrm{g} \mathrm{g}^{-1}\right)$ was used as the internal standard for Ami, Des, Dox, Imi, Nord and Nort, whereas imipramine $\left(40 \mu \mathrm{g} \mathrm{g}^{-1}\right)$ was used as the IS in analysis of patient's hair for Norc and Clo.

\section{Apparatus and conditions}

Hair samples (ca. $70 \mathrm{mg}$ ) were ground with a ball-grinder (Retsch, Germany) for $10 \mathrm{~min}$. A MARS X microwaveassisted sample preparation system (CEM, Matthews, USA), equipped with 14 pressurized 100-mL GreenChem PTFE vessels was used for isolation of the analytes from the hair matrix. An internal system enabled power and temperature to be regulated up to $1200 \mathrm{~W}$ and $240^{\circ} \mathrm{C}$, respectively.

A Merck-Hitachi LaChrom (Germany-Japan) highperformance liquid chromatograph consisting of an L-7100 pump, an L-7200 autosampler, and an L-7455 programmable diode-array detector coupled to a PC with D-7000 HSM software was used. The mobile phase was prepared by mixing acetonitrile and phosphoric buffer $(40: 60, v / v)$. Phosphoric buffer ( $\mathrm{pH}$ 2.36) was prepared by adding $1.4 \mathrm{~mL} 85 \%$ phosphoric acid and $1 \mathrm{~mL}$ diethylamine to a volumetric flask $(1 \mathrm{~L})$ and diluting to volume with deionized water. Before analysis the mobile phase was filtered with a modified cellulose filter $(0.45 \mu \mathrm{m})$ (Sartorius, Germany) and degassed in an ultrasonic bath. For each analysis, $10 \mu \mathrm{L}$ sample solution was injected by an autosampler and separation was carried out on a Spheri-5 $\mathrm{C}_{18}$ column, $100 \mathrm{~mm} \times 4.6 \mathrm{~mm}$ I.D., particle size

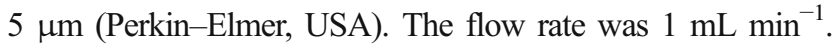
The column was thermostated at $50^{\circ} \mathrm{C}$. Chromatograms were acquired at $254 \mathrm{~nm}$ and calibration curves were calculated using peak-height ratios (drug/IS).

\section{Hair sample pretreatment}

Drug-free control hair samples were taken from volunteers with dark blond hair and stored in sealed polyethylene bags, at room temperature in a dry and dark place until analysis. Hair samples, cut from the vertex posterior, were collected from a patient who had been chronically treated with psychotropic drugs. Before analysis all hair samples were rinsed, using, in sequence, $0.1 \%$ sodium dodecylsulfate, water, acetone, and water to eliminate any external contamination. After drying at room temperature, the hair was cut into small pieces (ca. $2 \mathrm{~mm}$ long), ground, and $45 \mathrm{mg}$ powdered hair was weighed in a PTFE extraction vessel.

\section{Hair sample preparation}

Because no hair reference material was available for determination of tricyclic antidepressants, spiked samples were used throughout. The concentration of each drug was $4 \mu \mathrm{g} \mathrm{g}^{-1}$. To each sample $(45 \mathrm{mg}), 4 \mathrm{~mL} 1.0 \mathrm{~mol} \mathrm{~L}^{-1} \mathrm{NaOH}$ was added and the contents were then gently mixed. Extraction solvent ( $n$-hexane-isoamyl alcohol, 99:1, v/v, $5 \mathrm{~mL}$ ) was then added. Then the vessels were closed and placed in the microwave system, where, for $40 \mathrm{~min}$ at $60^{\circ} \mathrm{C}$, alkaline microwaveassisted hydrolysis (MAH) and microwave-assisted extraction (MAE) were performed simultaneously. The temperature and the composition of the extracting solvent were taken from a previous paper [27]. The other conditions were established during the optimization process described below. After the microwave-assisted procedure, the vessels were cooled to room temperature. Then, the contents of each vessel was transferred to a glass tube, using $1 \mathrm{~mL}$ organic solvent to rinse the vessel. Next, the glass tubes were closed and centrifuged for $10 \mathrm{~min}(4500 \mathrm{rpm})$. In the next step, $5 \mathrm{~mL}$ of the organic layer was separated and evaporated to dryness under a stream of nitrogen at $40{ }^{\circ} \mathrm{C}$. The residue was then dissolved in $250 \mu \mathrm{L}$ extraction solvent and backextracted into $50 \mu \mathrm{L} 0.05 \% \mathrm{H}_{3} \mathrm{PO}_{4}$. The centrifuged water layer was then taken for chromatographic analysis.

\section{Results and discussion}

\section{Optimization of MAH-MAE conditions}

To develop an effective and quick method of hair sample preparation for analysis of tricyclic antidepressant drugs, microwave irradiation was used in the preparation step. The objective of this procedure was to combine alkaline hair hydrolysis and solvent extraction in a single step. This combination provides a way of limiting operations on a sample and in this way the risk of sample and/or analyte loss is reduced. Moreover, because of the application of microwave assistance this procedure is less time-consuming and extraction efficiency is high.

In the preliminarily research, a combination of microwave-assisted hydrolysis (MAH) and microwave- 
Table 2 Hydrolysis and extraction procedures in the preliminary research

\begin{tabular}{|c|c|c|}
\hline & Simultaneous hydrolysis and extraction & Separate hydrolysis and extraction \\
\hline Procedure & $\begin{array}{l}\text { MAH-MAE: Add } 4 \mathrm{~mL} 0.6 \mathrm{~mol} \mathrm{~L}^{-1} \\
\mathrm{NaOH} \text { and } 5 \mathrm{~mL} \text { extraction solvent } \\
\text { to } 45 \mathrm{mg} \text { hair then start microwave oven }\end{array}$ & $\begin{array}{l}\text { MAH: Add } 1 \mathrm{~mL} 0.6 \mathrm{~mol} \mathrm{~L}^{-1} \mathrm{NaOH} \text { to } 45 \mathrm{mg} \\
\text { hair and run microwave oven ( } 15 \text { or } 30 \mathrm{~min} \text { ); } \\
\text { then cool to } 40^{\circ} \mathrm{C} \\
\text { MAE: Add } 3 \mathrm{~mL} 0.6 \mathrm{~mol} \mathrm{~L}^{-1} \mathrm{NaOH} \text { and } 5 \mathrm{~mL} \\
\text { extraction solvent and start microwave oven }\end{array}$ \\
\hline Process temperature $^{\mathrm{a}}$ & & $60^{\circ} \mathrm{C}$ \\
\hline Ramping time & $2 \min$ & $2 \min$ \\
\hline Time of hydrolysis & $\begin{array}{l}15 \mathrm{~min} \\
30 \mathrm{~min}\end{array}$ & $\begin{array}{l}15 \mathrm{~min} \\
30 \mathrm{~min}\end{array}$ \\
\hline Time of extraction & $-{ }^{\mathrm{b}}$ & $1 \min ^{\mathrm{a}}$ \\
\hline Extraction solvent ${ }^{\mathrm{a}}$ & Mixture of $n$-hexane and isoamyl alcohol $(99: 1, v / v)$ & \\
\hline
\end{tabular}

${ }^{\text {a }}$ Conditions adopted from previous experiments [27]

${ }^{\mathrm{b}}$ Extraction took place together with hydrolysis

assisted extraction (MAE) was investigated. Tricyclic antidepressants are mainly basic $\left(\mathrm{p} K_{\mathrm{a}}\right.$ ca. 9.5), so an alkaline solution was used to digest the hair sample. The high $\mathrm{pH}$ of the product obtained by hydrolysis offers the possibility of combining hydrolysis and extraction during preparation of hair samples.

Microwave-assisted hydrolysis and extraction procedures were carried out in two ways (Table 2) - simultaneously and separately (i.e. one after the other). The extraction conditions, for example extracting solvent, duration, and temperature of the process were well defined in our previous work [27]. A temperature of $60{ }^{\circ} \mathrm{C}$, found optimum for microwave-assisted extraction of tricyclic drugs [27], is also suitable for alkaline hydrolysis of hair. Application of a higher temperature may accelerate hair digestion, but also results in a risk of losing analytes or exceeding a safe organic vapor level in the microwave oven chamber. The authors found that application

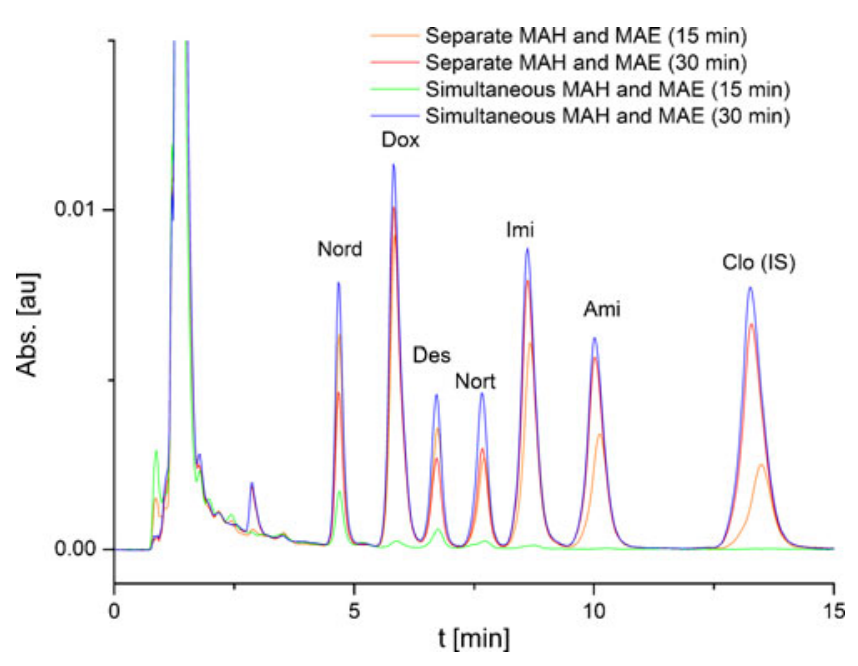

Fig. 1 Comparison of simultaneous and separate MAH-MAE procedures. Drug concentration $4 \mu \mathrm{g} \mathrm{g}^{-1}$ of $80{ }^{\circ} \mathrm{C}$ during simultaneous processes always led to loss of samples. Standard alkaline hydrolysis of hair samples followed by extraction usually takes more than an hour, but application of microwave heating should accelerate the processes, thus the evaluation was performed after 15 and $30 \mathrm{~min}$.

To find the best combination of MAH and MAE, the results obtained were compared in terms of efficiency, measured by peak height. The results obtained are presented in Fig. 1. Use of the process for 15 min was insufficient to enable successful isolation of analytes from hair structure, both for simultaneous and separate hydrolysis and extraction. Results obtained after 30 min indicated the superiority of MAH-MAE processes performed at the same time.

In the next step, two factors affecting microwave-assisted hydrolysis and extraction were taken into consideration: the

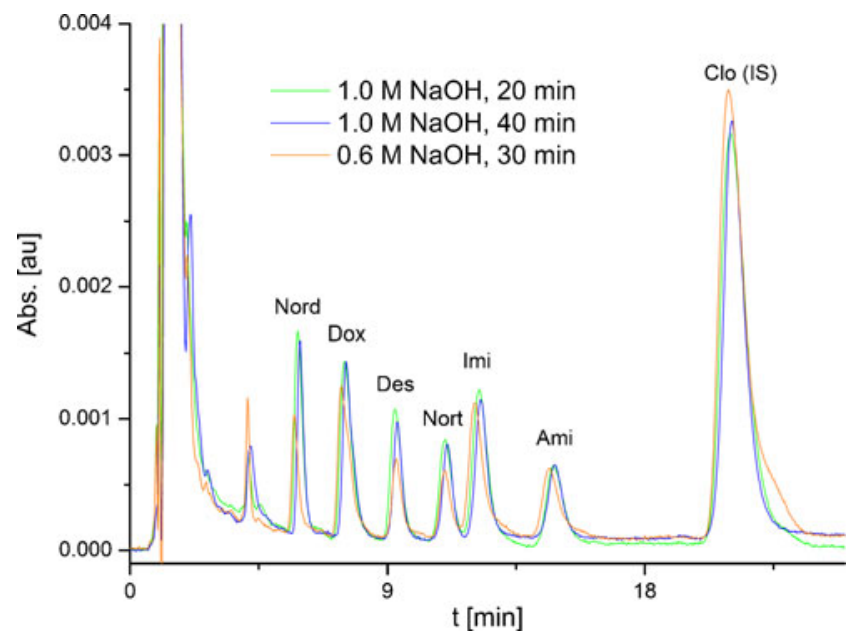

Fig. 2 Comparison of the effect of hydrolysis time and $\mathrm{NaOH}$ concentration on isolation of the studied drugs by the simultaneous MAH-MAE method 
Table 3 Results from validation of the MAH-MAE/HPLC method for analysis of eight TCADs

\begin{tabular}{|c|c|c|c|c|c|c|c|c|c|}
\hline \multirow{2}{*}{\multicolumn{2}{|c|}{ Internal standard }} & Nord & Dox & Des & Nort & Imi & Ami & $\mathrm{Clo}^{\mathrm{a}}$ & Norc $^{\mathrm{a}}$ \\
\hline & & Clo & Clo & Clo & Clo & Clo & Clo & Imi & Imi \\
\hline \multicolumn{2}{|l|}{ Linearity $\left(\mu \mathrm{g} \mathrm{g}^{-1}\right)$} & \multicolumn{8}{|c|}{ LOQ-20.0 $(n=4)$} \\
\hline \multicolumn{2}{|l|}{ Slope } & 0.097 & 0.125 & 0.067 & 0.0484 & 0.093 & 0.045 & 0.00466 & 0.0049 \\
\hline \multicolumn{2}{|l|}{ Intercept } & -0.074 & -0.041 & -0.029 & -0.0061 & -0.046 & -0.023 & -0.00075 & 0.0080 \\
\hline \multicolumn{2}{|l|}{ Correlation coefficient. $R^{2}$} & 0.9984 & 0.9977 & 0.9977 & 0.9999 & 0.9962 & 0.9940 & 0.9992 & 0.9976 \\
\hline \multicolumn{2}{|l|}{$\operatorname{LOD}\left(\mu \mathrm{g} \mathrm{g}^{-1}\right)$} & 0.9 & 0.5 & 1.1 & 1.1 & 0.3 & 0.7 & 0.7 & 1.2 \\
\hline \multicolumn{2}{|l|}{$\operatorname{LOQ}\left(\mu \mathrm{g} \mathrm{g}^{-1}\right)$} & 3.1 & 1.7 & 3.7 & 3.7 & 0.9 & 2.3 & 2.3 & 4.0 \\
\hline \multirow[t]{2}{*}{ Precision $4 \mu \mathrm{g} \mathrm{g}^{-1}$, RSD (\%) } & Intraday & 10.2 & 4.9 & 10.4 & 9.5 & 2.5 & 5.9 & 4.9 & 5.7 \\
\hline & Interday & 11.8 & 9.2 & 12.1 & 10.7 & 5.9 & 7.0 & 6.1 & 10.2 \\
\hline \multirow[t]{2}{*}{ Precision $10 \mu \mathrm{g} \mathrm{g}^{-1}$, RSD (\%) } & Intraday & 4.3 & 3.4 & 2.1 & 5.0 & 3.1 & 2.6 & 2.2 & 5.7 \\
\hline & Interday & 9.8 & 4.9 & 2.6 & 9.4 & 3.7 & 2.8 & 4.1 & 7.0 \\
\hline \multirow[t]{2}{*}{ Precision $18 \mu \mathrm{g} \mathrm{g}^{-1}$, RSD (\%) } & Intraday & 6.0 & 6.8 & 2.2 & 2.0 & 6.0 & 3.2 & 3.3 & 4.8 \\
\hline & Interday & 6.8 & 7.2 & 4.5 & 4.8 & 6.9 & 4.3 & 3.8 & 5.2 \\
\hline
\end{tabular}

duration of microwave exposure and the concentration of sodium hydroxide. The combined MAH-MAE method was carried out for 20, 30, and 40 min of effective microwave radiation time (ramping and cooling time excluded) using 0.6 and $1.0 \mathrm{~mol} \mathrm{~L}^{-1} \mathrm{NaOH}$. Each experiment was repeated four times $(n=4)$. The drug isolation efficiency was used as an evaluation factor: the ratio of the mean height of peaks recorded for all analytes when a sample was determined to the analogous value obtained for the standard drug solution (with analytes at the same concentrations). When the process was performed with use of $0.6 \mathrm{~mol} \mathrm{~L}^{-1} \mathrm{NaOH}$ for $20 \mathrm{~min}$, it was found to be evidently inefficient. Application of $1.0 \mathrm{~mol} \mathrm{~L}^{-1} \mathrm{NaOH}$ for 20 and $40 \mathrm{~min}$ resulted in significantly higher extraction efficiency (Fig. 2), but the repeatability of the 20 -min process $(13.3 \%)$ was poorer than that obtained after $40 \min (5.8 \%)$.

Finally, the optimum conditions for the MAH-MAE process were selected as 40 min with $1.0 \mathrm{~mol} \mathrm{~L}^{-1} \mathrm{NaOH}$. Under these conditions, extraction efficiency for each drug ranging from $101.1 \%$ (Dox) to $108.3 \%$ (Ami) was achieved.

\section{Validation step}

Validation of the MAH-MAE/HPLC-DAD method for determination of eight tricyclic antidepressants and their metabolites in human hair was performed. For determination of Ami, Des, Dox, Imi, Nord, and Nort, clomipramine was used as an internal standard whereas for determination of Clo and Norc, imipramine was used. The results are presented in Table 3.

The limits of detection (LOD) and quantification (LOQ) were calculated as three times and ten times the SD-toslope coefficient ratio, respectively. The LOD ranged from $0.3 \mu \mathrm{g} \mathrm{g}^{-1}$ for imipramine to $1.1 \mu \mathrm{g} \mathrm{g}^{-1}$ for desipramine and nortriptyline, whereas the LOQ varied from $0.9 \mu \mathrm{g} \mathrm{g}^{-1}$ for imipramine to $4.0 \mu \mathrm{g} \mathrm{g}^{-1}$ for norclomipramine. The linear range was expressed as the range from the LOQ to

Table 4 Recovery of TCADs from human hair by use of simultaneous MAH-MAE $(n=4)$

\begin{tabular}{|c|c|c|c|c|c|c|c|c|c|c|c|c|}
\hline \multirow[t]{2}{*}{ Drug } & \multicolumn{4}{|c|}{ Low concentration $\left(\mu \mathrm{g} \mathrm{g}^{-1}\right)$} & \multicolumn{4}{|c|}{ Medium concentration $\left(\mu \mathrm{g} \mathrm{g}^{-1}\right)$} & \multicolumn{4}{|c|}{ High concentration $\left(\mu g g^{-1}\right)$} \\
\hline & Expected & Found & Recovery (\%) & RSD (\%) & Expected & Found & Recovery (\%) & RSD (\%) & Expected & Found & Recovery (\%) & RSD (\%) \\
\hline Nord & 4.0 & 3.6 & 88.8 & 10.7 & 10.0 & 9.1 & 91.1 & 6.7 & 18.0 & 18.0 & 100.0 & 5.0 \\
\hline Dox & & 4.0 & 99.8 & 4.0 & & 10.4 & 103.1 & 5.6 & & 17.5 & 97.2 & 6.8 \\
\hline Des & & 3.6 & 89.8 & 11.1 & & 9.9 & 96.8 & 9.2 & & 17.8 & 98.9 & 1.7 \\
\hline Nort & & 3.7 & 91.3 & 11.9 & & 9.4 & 91.6 & 5.1 & & 17.8 & 98.9 & 1.9 \\
\hline Imi & & 4.1 & 103.5 & 2.7 & & 10.4 & 99.9 & 3.3 & & 17.4 & 96.7 & 5.9 \\
\hline Ami & & 4.4 & 110.3 & 3.8 & & 10.7 & 101.4 & 2.9 & & 17.4 & 96.7 & 3.5 \\
\hline Norc & & 4.1 & 101.5 & 9.9 & & 10.3 & 97.1 & 5.4 & & 17.7 & 98.3 & 3.1 \\
\hline Clo & & 4.4 & 110.8 & 4.9 & & 11.3 & 105.5 & 2.1 & & 17.9 & 99.4 & 2.8 \\
\hline
\end{tabular}




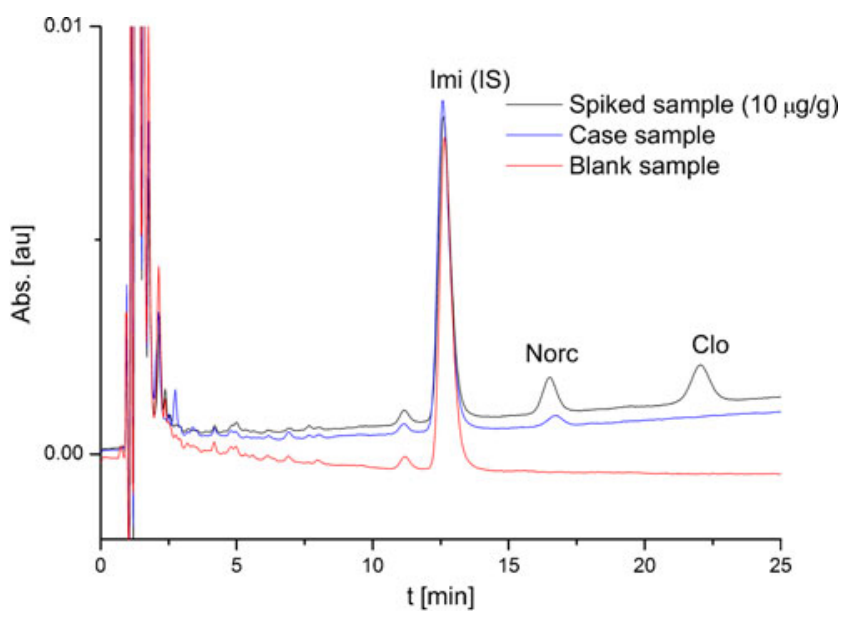

Fig. 3 Results from analysis of patient's hair

the maximum measured concentration $\left(20 \mu \mathrm{g} \mathrm{g}^{-1}\right)$ for which $R^{2}>0.994$. The values obtained enabled analysis of TCADs present in hair at average therapeutic levels.

The precision of the method, expressed as the repeatability of the measured concentration was estimated by analysis of four different hair samples spiked with analytes at concentrations of $4.0,10$, and $18.0 \mu \mathrm{g} \mathrm{g}^{-1}$. The measurements were repeated on another day. In this way, intraday and interday precision was calculated. The results obtained revealed (Table 3) that for low and medium concentrations, application of the simultaneous MAH-MAE method with HPLC-DAD determination was more precise for less polar parent TCADs (amitriptyline, imipramine, doxepin, and clomipramine) than for metabolites.

The recovery $(R)$ was calculated as the ratio of the found concentration $\left(c_{\mathrm{f}}\right)$ to the expected concentration $\left(c_{\mathrm{e}}\right)$, after spiking a sample:

$R=\frac{c_{f}}{c_{e}} \cdot 100 \%$

The results obtained from analysis of four samples are presented in Table 4. The recoveries, calculated for all the analytes, ranged from 88.8 to $110.8 \%$ at low concentration $\left(4 \mu \mathrm{g} \mathrm{g}^{-1}\right)$, from 91.1 to $105.5 \%$ at medium concentration $\left(10 \mu \mathrm{g} \mathrm{g}^{-1}\right)$, and from 96.7 to $100.0 \%$ at high concentration $\left(18 \mu \mathrm{g} \mathrm{g}^{-1}\right)$.

\section{Case study}

A 32-year-old woman (with ca. $20 \mathrm{~cm}$ long, blond, not bleached or dyed hair) suffering from depression, was treated with $112.5 \mathrm{mg}$ Anafranil (clomipramine hydrochloride, Novartis, Switzerland) daily for one year and then at $25 \mathrm{mg}$ per day for the following 6 months (18 months before collection of hair samples). Because the authors wanted to check if clomipramine or its nor-metabolite were present in her hair, a strand ca. $20 \mathrm{~cm}$ long from the vertex posterior of the head and $4 \mathrm{~cm}$ long endings were taken for analysis. Studies were carried out for four samples (endings) and a blank hair sample, $45 \mathrm{mg}$ each. All samples were spiked with internal standard (imipramine) and treated according to the optimized MAH-MAE method. The extracts obtained were then analyzed by HPLC-DAD. Results from analysis revealed only a peak corresponding to norclomipramine (Fig. 3). Peak identification was confirmed by comparison of UV spectra; the concentration of norclomipramine in hair was $5.3 \pm 0.3 \mu \mathrm{g} \mathrm{g}^{-1}$.

The absence of clomipramine could have been caused by the different polarity of the parent drug and its metabolite and by the properties of the hair. The more polar desmethyl metabolite norclomipramine is more slowly eliminated from hair than the parent drug. Moreover, for tricyclic antidepressants, the mean drug concentration slowly decreases with increasing distance from the hair root (i.e., increasing age of the hair). So that after more than one year in the hair, (i.e. more than $12-15 \mathrm{~cm}$ from the root), about $4 \%$ of the drugs remain present [13]. The hair samples of the patient were taken after she had finished 18 months of treatment with Anafranil. It is possible that only a small amount (less than the LOD) of clomipramine remained in the patient's hair.

\section{Conclusion}

Within the framework of this study, a modern simultaneous MAH-MAE method for hair sample preparation, before analysis of tricyclic antidepressant drugs in human scalp hair by use of HPLC-DAD, was developed. It combines two laborious hair-sample-preparation steps: alkaline hydrolysis and extraction of analytes in a single operation. Because of this combination, the procedure proposed is evidently less time-consuming and more effective than the conventional sample preparation procedure involving alkaline hydrolysis. According to the literature [18], the efficiency of classic liquid extraction ranges from 64.6 to $88.1 \%$, whereas the authors' method is characterized by efficiency close to $100 \%$. Moreover, the fact that these processes are performed together, that up to 14 samples can be prepared in a single microwave oven run, and that samples only have to be cooled once are great advantages of the proposed procedure. It should also be emphasized that application of microwave energy supports both alkaline hydrolysis and extraction, thus high recovery of tricyclic antidepressant drugs was achieved.

Analysis of the real hair sample collected from the patient treated with tricyclic antidepressants confirmed the reliability of the method.

The results obtained show that the method is reliable and may be used in clinical laboratories for therapeutic 
monitoring of TCADs and in forensic laboratories for their analysis at therapeutic and higher levels in human hair.

Open Access This article is distributed under the terms of the Creative Commons Attribution Noncommercial License which permits any noncommercial use, distribution, and reproduction in any medium, provided the original author(s) and source are credited.

\section{References}

1. Balikova MA, Habrdova V (2003) J Chromatogr B 789:93-100

2. Villain M, Crimele V, Kintz P (2004) Clin Chem Lab Med 42 (11):1265-1272

3. Gaillard Y, Pepin G (1999) J Chromatogr B 733:231-246

4. Musshoff F, Madea B (2007) Forensic Sci Int 165:204-215

5. Wada M, Ikeda R, Kuroda N (2010) Nakashima. Anal Bioanal Chem 397:1039-1067

6. Kintz P (2007) Anal Bioanal Chem 388:1467-1474

7. Zimmermann CM, Jackson GP (2010) Ther Drug Monit 32:216-223

8. Kintz P, Crimele V, Gosselin O, Edel Y, Mangin P (1996) Ann Biol Clin 54:317-318

9. Pragst F, Rothe M, Hunger J, Thor S (1997) Forensic Sci Int 84:225-236

10. Beumer JH, Bosman U, Maes R (2001) Int J Clin Pract 55(6):353-357

11. Nakahara Y (1999) J Chromatogr B 733:161-180

12. Kintz P (2004) Forensic Sci Int 142:127-134

13. Pragst F, Balikova MA (2006) Clin Chim Acta 370:17-19

14. Casper JL (1857-1858) In: Hirschwald A (ed) Praktisches Handbuch der Gerichtlichen Medizin, 2 vols, Berlin

15. Baumgartner AM, Jones PF, Baumgartner W, Black CT (1979) J Nucl Med 20:748-752

16. Hawton K, Bergen H, Simkin S, Cooper J, Waters K, Gunnell D, Kapur N (2010) Br J Psychiatry 196:354-358

17. Kłys M, Ścislowski M, Rojek S, Kołodziej J (2005) Leg Med 7:319-325
18. Shen M, Xiang P, Wu H, Shen B, Huang Z (2002) Forensic Sci Int 126:153-161

19. Kłys M, Rojek S, Moskała A (2003) Probl Forensic Sci 54:76-99

20. Couper FJ, McIntyre IM (1995) Drummer 0. J Forensic Sci 40:87-90

21. Miguez-Framil M, Moreda-Pineiro A, Bermejo-Barrera P, Lopez P, Tabernero MJ, Bermejo AM (2007) Anal Chem 79:8564-8570

22. Alvarez I, Palos F, Bermejo AM, Fernandez P, Tabernero MJ (2006) Anal Lett 39:1393-1399

23. Pelander A, Ristimaa J, Rasanen I, Vouri E, Ojanpera I (2008) Ther Drug Monit 30:717-724

24. Sporkert F, Pragst F (2000) Forensic Sci Int 107:129-148

25. Couper FJ, McIntyre IM (1995) Drummer 0. J Forensic Sci 40:83-86

26. Gaillard Y, Pépin G (1997) J Chromatogr A 762:251-267

27. Woźniakiewicz M, Wietecha-Posłuszny R, Garbacik A, Kościelniak P (2008) J Chromatogr A 1190:52-56

28. Abu-Samara A, Morris JS, Koirtyohann SR (1975) Anal Chem 47:1475

29. Wietecha-Posłuszny R, Woźniakiewicz M, Garbacik A, Kościelniak P (2007) Probl Forensic Sci 70:187-197

30. Fernandez P, Lago M, Lorenzo RA, Carro AM, Bermejo AM, Tabernero MJ (2007) J Anal Toxicol 31:388-393

31. Fernandez P, Vazquez C, Lorenzo RA, Carro AM, Alvarez I, Cabarcos P (2010) Anal Bioanal Chem 397:677-685

32. Fernandez P, Lago M, Lorenzo RA, Carro AM, Bermejo AM, Tabernero MJ (2007) J Appl Toxicol 27:373-379

33. Fernandez P, Moralez L, Vazquez C, Lago M, Bermejo AN (2008) J Appl Toxicol 28:998-1003

34. Fernandez P, Lago M, Lorenzo RA, Carro AM, Bermejo AM, Tabernero MJ (2009) J Chromatogr B 877:1743-1750

35. Eskilsson CS, Bjorklund E, Mathiasson L, Karlsson L, Torstensson A (1999) J Chromatogr A 840:59-70

36. Labbozzetta S, Valvo L, Bertocchi P, Manna L (2005) J Pharm Biomed 39:463-468

37. Alvarez I, Bermejo AM, Tabernero MJ, Fernandez P, Cabarcos P, Lopez P (2009) Anal Bioanal Chem 393:1345-1350 